Discussion Paper No. 08-037

\title{
Market and Technology Access Through Firm Acquisitions: Beyond One Size Fits All
}

Christoph Grimpe and Katrin Hussinger

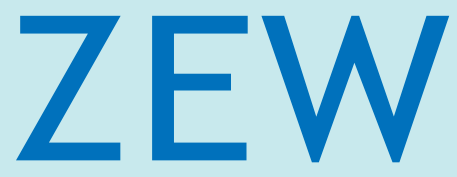

Zentrum für Europäische Wirtschaftsforschung $\mathrm{GmbH}$ Centre for European Economic Research 
Discussion Paper No. 08-037

\section{Market and Technology Access Through Firm Acquisitions: Beyond One Size Fits All}

Christoph Grimpe and Katrin Hussinger

Download this ZEW Discussion Paper from our ftp server:

ftp://ftp.zew.de/pub/zew-docs/dp/dp08037.pdf

Die Discussion Papers dienen einer möglichst schnellen Verbreitung von neueren Forschungsarbeiten des ZEW. Die Beiträge liegen in alleiniger Verantwortung der Autoren und stellen nicht notwendigerweise die Meinung des ZEW dar.

Discussion Papers are intended to make results of ZEW research promptly available to other economists in order to encourage discussion and suggestions for revisions. The authors are solely responsible for the contents which do not necessarily represent the opinion of the ZEW. 


\section{Non-technical summary}

Recent literature has emphasized several motivations behind mergers and acquisitions (M\&As). Firm acquisitions have been shown to serve as a way to gain access to international markets, technological assets, product lines or other valuable resources of the target firm. Little is known, however, about how these different take-over motivations are linked to the size of the transaction. Is the importance of technological assets more pronounced for small acquisition targets? Do firms enter new geographical markets through the acquisition of large players in foreign markets? On the one hand, smaller target firms might have important intellectual property rights which larger firms might be willing to access in order to prevent competitors from entering the technology market. Smaller firms are presumably easier to integrate into the acquirer and hence their technological assets easier to access. On the other hand, larger targets may provide better access to markets and established products as these firms typically also have a higher market share and a better distribution network. Larger acquisitions should hence also tend to be cross-border rather than domestic. Given this heterogeneity of takeover motivations and the skewness of the distribution of the deal value we investigate whether standard estimation procedures that focus on the average acquisition target in order to unveil the underlying takeover motivation show the complete picture. Based on a comprehensive dataset of 652 M\&A transactions in the period from 1997 to 2003, we use quantile regressions to analyze heterogeneity in takeover motivations along the deal value distribution. Our results indicate that the importance of technological assets, measured by the patent stock, is indeed higher for target firms associated with a lower deal value. The findings support the view on smaller acquisitions to complement the acquirer's technology portfolio while large acquisitions tend to be used to gain access to non-technological assets and to international markets. 


\section{Das Wichtigste in Kürze}

Ziele und Motivationen von Fusionen und Unternehmensübernahmen (M\&As) sind in der vergangenen Zeit häufig Gegenstand wissenschaftlicher Analysen gewesen. So wurde gezeigt, dass Firmenakquisitionen genutzt werden, um Zugang zu internationalen Märkten, Technologien und anderen wertvollen Ressourcen der Zielfirmen zu erhalten. Wenig ist jedoch darüber bekannt, wie sich die Bedeutung der verschiedenen Gründe für eine Übernahme bei unterschiedlicher Größe der Zielunternehmen ändert. Erschließen Unternehmen geographisch neue Märkte durch die Übernahme von großen Akteuren in Auslandsmärkten? Ist der Zugang zu neuen Technologien von größerer Bedeutung bei kleinen Zielunternehmen? Einerseits könnten kleine Firmen wichtige intellektuelle Eigentumsrechte besitzen, und Käuferunternehmen könnten so zukünftige Konkurrenten im Technologiemarkt abhalten. Kleinere Firmen sind vergleichsweise billiger, weshalb die Nutzung ihres Wissens durch Integration attraktiver erscheinen könnte als der Erwerb von lizenzierter Technologie. Andererseits könnten größere Zielfirmen einen besseren Zugang zu Märkten und etablierten Produkten darstellen, da diese Firmen in der Regel auch über einen höheren Marktanteil und ein besseres Vertriebsnetzwerk verfügen. Größere Akquisitionen sollten demnach eher auf internationaler Ebene stattfinden als im Heimatmarkt. In Anbetracht dieser Vielfalt an Übernahmemotiven und der ungleichen Verteilung des Verkaufswerts, untersucht diese Studie, ob statistische Verfahren, die sich auf ein durchschnittliche Zielunternehmen konzentrieren, um Aufschluss über zu Grunde liegende Übernahmemotivationen zu geben, das ganze Bild zeigen. Auf Basis eines umfassenden Datensatzes von 652 europäischen Fusionen und Übernahmen im Zeitraum von 1997 bis 2003 benutzen wir Quantilsregressionen um die Heterogenität von Übernahmemotiven im Zusammenhang mit unterschiedlichen Verkaufswerten $\mathrm{zu}$ untersuchen. Unsere Ergebnisse zeigen, dass der Zugang zu neuen Technologien tatsächlich eine größere Rolle bei Zielunternehmen mit geringerem Verkaufswert spielt. Unsere Untersuchung stützt auch die Ansicht, dass kleinere Akquisitionen getätigt werden, um das Technologieportfolio des Käufers zu vervollständigen, während große Akquisitionen meist Zugang zu nicht-technologischen Vermögensgegenständen und internationalen Märkten verschaffen sollen. 


\title{
Market and Technology Access Through Firm Acquisitions: Beyond One Size Fits All
}

\author{
Christoph Grimpe ${ }^{\text {a,b }}$ and Katrin Hussinger ${ }^{\text {c,b,a }}$ \\ ${ }^{a}$ Centre for European Economic Research (ZEW), Mannheim (Germany) \\ ${ }^{b}$ Catholic University of Leuven (Belgium) \\ ${ }^{c}$ University of Maastricht (Netherlands)
}

\begin{abstract}
Firm acquisitions have been shown to serve as a way to gain access to international markets, technological assets, products or other valuable resources of the target firm. Given this heterogeneity of takeover motivations and the skewness of the distribution of the deal value we show whether and how the importance of different takeover motivations changes along the deal value distribution. Based on a comprehensive dataset of 652 European mergers and acquisitions in the period from 1997 to 2003, we use quantile regressions to decompose the deal value at different points of its distribution. Our results indicate that the importance of technological assets is indeed higher for smaller target firms. The findings support the view on small acquisition targets to complement the acquirer's technology portfolio while larger acquisition targets tend to be used to gain access to international markets.

Keywords: Firm acquisitions, technological assets, market access, quantile regression JEL: G34, L20, O34

Email correspondence: grimpe@zew.de, k.hussinger@os.unimaas.nl
\end{abstract}




\section{Introduction}

The year 2007 marked a new record high for worldwide merger and acquisition (M\&A) activity with more than 3.3 trillion Euros in total deal value spread over 59,000 transactions. ${ }^{1}$ While mega-mergers are closely observed by the public, the majority of acquisitions that target at small and medium-sized enterprises (SME) receives almost no attention. This is surprising as acquisitions of small firms have been shown to be highly important in many industries, for example, in the beer industry (Sutton, 1991), but also in high-technology sectors like biotechnology (Graff et al., 2003). Whereas small firms in the beer industry are attractive because of their retail outlets, SMEs in high-tech sectors are attractive acquisition targets because of their technological assets and intellectual property rights. In fact, the distribution of the deal value appears to be highly skewed: The vast majority of deals is rather small. Figure 1 shows a histogram for the deal value for more than 8,300 M\&A transactions in which either acquiring or target firms from the EU-27 were involved in 2007.

\section{Figure 1: Skewness of the deal value distribution}

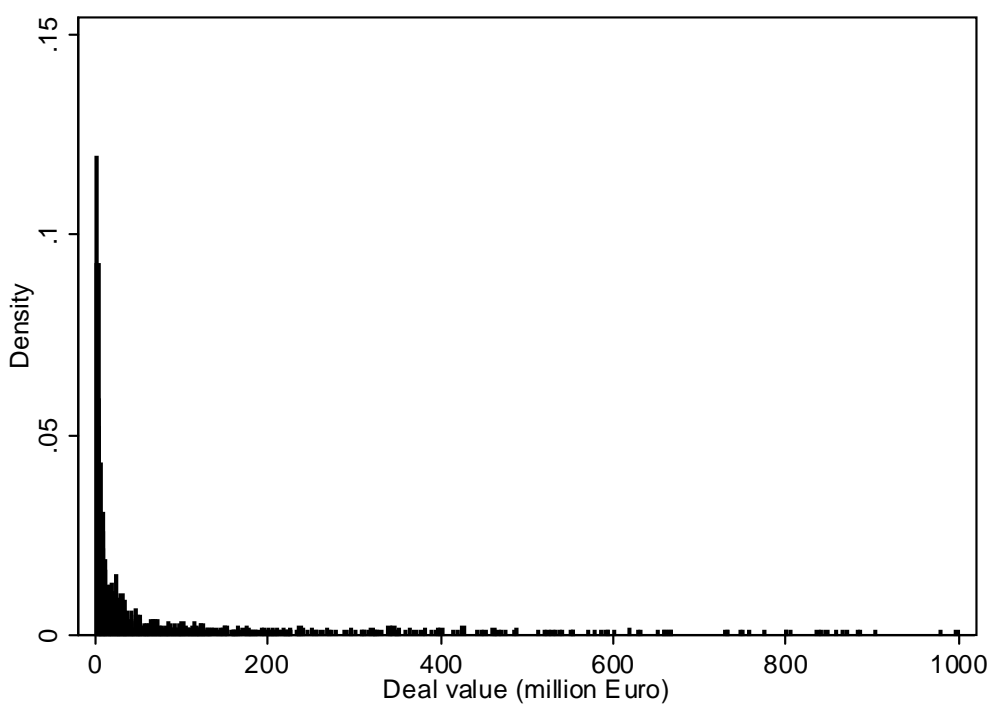

Merger objectives have been shown to range from gaining access to international markets (e.g., Dunning, 1988), accessing technological assets and intellectual property rights (e.g., Ahuja and Katila, 2001; Graebner, 2004), or to buying certain product lines and other valuable resources of the target firm (Griliches, 1981; Pakes, 1985).

\footnotetext{
${ }^{1}$ Source: ZEPHYR database, Bureau van Dijk Electronic Publishing.
} 
The heterogeneity of merger objectives along with the skewness of the deal value distribution suggests, however, that there is no common story behind M\&A objectives. Yet, previous literature has failed to expose different takeover motives behind smaller and larger deals. Standard regression techniques usually focus on the "average firm", implicitly assuming that there is a common story to tell about all transactions. When it comes to investigating merger objectives it is questionable, however, whether this can provide the full picture. If an acquisition was targeted at particular intellectual property rights (O'Donoghue et al., 1998; Lerner et al., 2003) or an innovative product line (Black, 2000) we would expect this to be achieved rather through a smaller acquisition target as takeovers can be more attractive in such cases than technology licensing agreements because the costs of governance are likely to be smaller than the costs of licensing (hold up-problems, value allocation problems, etc.) (Graff et al., 2003). Moreover, smaller firms tend to exhibit a higher level of creativity and innovativeness which, for example large pharmaceutical firms wish to exploit when acquiring small and innovative biotechnology firms (Teece, 1988). After all, they also seem to be easier to integrate (Grimpe, 2007). Contrary to this, acquisition targets can be big players in the market that provide the acquiring firm with the entry to a foreign market, with a large market share, product portfolio and a well developed distribution and customer network (Caves, 1989; Scherer and Ross, 1990; Röller et al., 2001). Moreover, the acquisition of a large player in the market immediately reduces competition. Given the intention to quickly enter a foreign market, acquisitions associated with a high deal value are hence likely to be cross-border rather than domestic (Dunning, 1988).

Given the heterogeneity of M\&A objectives, this study shifts focus from the average acquisition target to the entire distribution of M\&A targets. We contribute to the literature by analyzing different takeover motivations in a multivariate setting. The high skewness of the deal value distribution strongly points at heterogeneity of acquisition targets and underlying motivations, so that the average effect might not be very meaningful. We add to the previous literature by leaving behind the concept of the average acquisition target and focus on the whole distribution of the deal value in order to investigate the importance of different merger objectives. Our results uncover different motivations underlying the acquisitions of SMEs and large firms. Using quantile regression, we show how the importance of different firm characteristics 
changes along the deal value distribution. As opposed to standard regression techniques that focus on the average acquisition and average motivation quantile regression provides a more complete picture of takeover motivations as it provides insights at different parts of the deal value distribution.

Our empirical analysis is based on a comprehensive dataset of 652 European mergers and acquisition in the period from 1997 to 2003. The results indicate that the importance of technological assets is indeed higher for smaller target firms while nontechnological assets explain the largest share of the acquisition price of larger targets. The findings support the view of smaller acquisitions to complement the acquirer's technology portfolio. Further, acquisitions of large firms tend to be used to gain access to international markets rather than small firm acquisitions.

The remainder of the paper is organized as follows. The next sections provide a short review on takeover motivations before we will outline our theoretical considerations and establish a set of hypotheses. Section 4 introduces the data set we use and presents descriptive statistics. The empirical test of our hypotheses is provided subsequently. Section 6 discusses our results and provides policy and managerial implications. The last section concludes with a critical evaluation of the study and points out potential areas for further research.

\section{A brief review of takeover motivations}

Previous literature has suggested that gaining access to technology and to geographical markets may be characterized as the two major motives for engaging in an M\&A transaction. Technology-related M\&As have received quite some attention by economists and management researchers in the recent past. Industrial organization economics put emphasis on market power and efficiency gains as major drivers of M\&A activity (Caves, 1989; Scherer and Ross, 1990; Röller et al., 2001). These merger objectives can be taken forward to technology markets (Cassiman et al., 2005). On the one hand, firm acquisitions are carried out to realize economies of scale and economies of scope in research and development (R\&D) (Bertrand and Zungia, 2006; Cassiman et al., 2005). On the other hand, horizontal acquisitions may reduce competition and increase market power in technology markets (Chakrabarti et al., 1994; Mukherjee et al., 2004). Complementary to this perspective, strategy researchers have argued that M\&A transactions can be used to reconfigure the 
acquirer's or target's business, in order to respond to changes in the competitive environment or to enhance and improve existing operations (e.g., Bowman and Singh, 1993; Capron et al., 1998; Capron and Hulland, 1999). Reconfiguring the business goes along with a redeployment of resources which, in case of $R \& D$, may involve intellectual property rights, personnel, laboratories and technical instruments being physically transferred to new locations or used in different R\&D projects. Such resource-based motivations for acquisitions have gained a lot of attention in the strategy literature. Moreover, the combination of two product or technology portfolios provides an opportunity to exploit complementarities (Ahuja and Katila, 2001; Colombo et al., 2006) that result from a skilled unbundling or bundling of resources with the objective to enhance (technological) core competencies of the merged entity (Cassiman et al., 2005; Sorescu et al., 2007).

Besides technology, non-technological motivations may play a vital role in the decision to acquire a potential target. Those motivations tend to receive most importance in the trade-off between an acquisition and a greenfield investment (Görg, 2000). In contrast to greenfield investments, acquisitions provide the acquiring firm almost immediately with an existing product portfolio customized to the market as well as with a developed distribution and customer network (Caves, 1989; Scherer and Ross, 1990; Röller et al., 2001). Moreover, competition in this market can be reduced. These benefits tend to be higher the larger the target firm is.

In addition, M\&As can be used to access foreign, i.e. not domestic, markets. Particularly in Europe, the past decades were characterized by an increased integration of markets as a consequence of the deepening of the European Union and the set-up of the European Monetary Union. After the abolishment of significant barriers to the free flow of capital, labor and trade between countries, M\&As were, besides foreign direct investment, one of the major means to gain access to foreign European markets (Kleinert and Klodt, 2000). Foreign acquisition targets are attractive due to their familiarity with local consumer tastes, rules and the culture of the labor market, effective ways of advertising, the distribution network, government regulations, and market interactions between suppliers, consumers and competitors (Görg, 2000; Qiu and Zhou, 2006). 


\section{Analytical framework}

Carrying out an acquisition involves the payment of a certain acquisition price, either for shares at the stock market or in a private sale. Acquiring firms will presumably pay a higher price for a target the more pronounced their takeover motivations are. Financial market efficiency suggests that the market value of a firm reflects the available information that relates to its current and future profitability (Fama, 1970). Jensen and Ruback (1983) have argued that acquisitions typically involve a significant positive premium over the market value of the target firm, which suggests that some acquirers put a higher value on the acquisition target than the market does. Previous literature provides a number of explanations for the attractiveness of certain targets beyond its actual market value ranging from their product market position to their intellectual property rights to their engagement in foreign markets. This section gives an overview on how these major merger motivations - technology and markets - translate into the acquisition price.

\subsection{Technological relatedness, content and the value of technology}

Previous literature has shown that that technological relatedness is a major factor for the success of M\&As along with product market relatedness (Ahuja and Katila, 2001; Cassiman et al., 2005). In case of related strengths and core competencies acquiring firms can maximize complementarity effects from bundling strategic resources into unique and valuable combinations (Barney, 1991; Conner, 1991; Peteraf, 1993). Through this process of resource redeployment (Capron et al., 1998; Capron and Hulland, 1999), a merged entity may create a new or improved set of capabilities providing the basis for superior firm performance and competitive advantage (Penrose, 1959; Eisenhardt and Martin, 2000; Priem and Butler, 2001; Sorescu et al., 2007). Hence, acquiring firms presumably screen technology markets carefully in search for acquisition targets that will most effectively complement their technology portfolio.

An important precondition for identifying valuable resources of a target firm is the ability of an investor to judge and value the potential of externally available technologies, which is summarized in the literature as the absorptive capacity of a firm (Cohen and Levinthal, 1989, 1990). Absorptive capacity is the ability to identify valuable technological knowledge in the environment, assimilate and finally exploit it 
in combination with existing know-how for successful innovation. In general, absorptive capacities increase awareness for market and technology trends, which can be translated into pre-emptive actions (Bowman and Hurry, 1993; Grimpe and Hussinger, 2008). As a result, they enable firms to predict future developments more accurately (Cohen and Levinthal, 1994). Acquirers who wish to realize complementarities have typically developed expertise and absorptive capacities as a by-product of R\&D activities in a particular technology field (Cohen and Levinthal, 1989, 1990).

An alternative theoretical perspective on the ability of an acquiring firm to judge the value of externally available technologies has emerged from the literature on information asymmetries in investment decisions (e.g., Aboody and Lev, 2000; Cohen and Dean, 2005; Heeley et al., 2007). Generally speaking, acquirers face the challenge of evaluating the innovation activities of a potential target in the absence of detailed information on every single innovation project. Each innovation project is characterized by its own specific attributes which are generally kept secret by a firm to appropriate the returns from innovation. In addition to their in-house expertise, acquirers may use publicly available information sources like patent data to assess the value of a firm's innovation activities (Heeley et al., 2007). In order for a patent to be granted, the technological content of the patent needs to be disclosed by the applicant to the patent office. As it is highly technical information, providing only those "skilled in the art" with relevant knowledge about the true content, there is again substantial information asymmetry between informed and uninformed acquirers. This difference becomes even more pronounced when technological complexity increases, as is typical for high-technology industries (Hagedoorn and Duysters, 2002).

Drawing from the theory of absorptive capacity and information asymmetries, we hence hypothesize that acquirers with technological expertise acquired through R\&D activities in a particular field can better judge the value of a target's technological assets. Furthermore, the combination of the acquiring firm's technologies with related knowledge stocks of the target may lead to complementarity effects (Cassiman and Veugelers, 2005). Lastly, firms active in the same technology field as the acquirer may own patents and other intellectual property rights that block ongoing research within the acquiring company (O'Donoghue et al., 1998; Lerner et al., 2003). An acquisition can solve legal disputes over intellectual property rights and unlock 
blocked lines of research (Graff et al., 2003). Through a similar vein, firms can also engage in M\&As to pre-empt competition in technology markets (Grimpe and Hussinger, 2008). Taking all those arguments together, our first hypothesis reads:

Hypothesis 1a: The price paid for an acquisition target increases if the acquiring and target firm are active in related technology fields.

Furthermore, it is sensible to distinguish between the size of the technology portfolio to be acquired and its quality. In the first place, a patent acts as a positive signal as it shows that the prospective target firm has proven its technological expertise and capabilities and that it has a well-functioning laboratory and inventor team (Ndofor and Levitas, 2004; Levitas and McFadyen, 2006; Heeley et al., 2007). This holds also for acquiring firms that lack technological background or that engage in an acquisition in order to enter a new technology line. Moreover, patents have a value because they can be sold individually after the acquisition. Hence, our second hypothesis reads:

Hypothesis 2a: The price paid for an acquisition target increases with the target's patent stock.

Given the discussion on absorptive capacity, we argue that acquiring firms will also be able to identify valuable technological resources, i.e. high-quality patents. Our third hypothesis hence reads:

Hypothesis 3a: The price paid for an acquisition target increases with the value of the target's patents.

Going beyond an average effect of technological assets, we hypothesize that information asymmetries are more pronounced for small firms (Shen and Reuer, 2005; Capron and Shen, 2007). Those firms are often privately held and young so that it is more difficult to access company information and especially information about their technological capabilities for outsiders to the technology field. Furthermore, the acquisition of small firms counteracts their potential of those firms to become strong competitors in future technology markets and the price paid for the acquisition target can outweigh this threat of future competition. From a transaction cost point of perspective (Williamson, 1985), the costs of exploiting new knowledge internally through firm acquisitions, as opposed to an external exploitation through technology licensing contracts at arm's-lengths, has to outweigh the costs of the increase in governance. For small firms the acquisition and post-merger integration costs can be 
below technology licensing costs. Besides monetary costs, these costs are incurred through problems due to multiple ownership of patents that protect one technology in the presence of a fragmented technology space with mutual blocking patents (Heller and Eisenberg, 1998; Shapiro, 2001), value allocation and hold-up problems between the contracting parties, monitoring problems and strategic problems from rentdissipating as a side effect of licensing that can also lead to new competitors (Graff et al., 2003; Ziedonis, 2004). Hence, the fact whether a potential acquisition target is operating in a related technology field will be more important for smaller targets as acquirers will be better able to evaluate the technologies employed. This will presumably result in a higher premium paid for those smaller targets relative to the premium paid to related but larger targets.

Hypothesis 1b: The price paid for an acquisition target in related technology fields is relatively higher for $M \& A s$ with a lower deal value than for those with a higher deal value.

Given the discussion on transaction costs, we argue that technological assets are relatively more important for the acquisition of small firms because large firms are more likely to rely on engaging in technology licensing than in takeovers in the first place. This should be reflected in the size of the patent portfolio and its value. Hence, we hypothesize:

Hypothesis 2b: The price paid for an acquisition target's patent stock is relatively higher for $M \& A s$ with a lower deal value than for those with a higher deal value.

Carrying forward the argument to the value of the acquired technology our last technology-related hypothesis reads:

Hypothesis 3b: The price paid for an acquisition target's value of patents is relatively higher for $M \& A s$ with a lower deal value than for those with a higher deal value.

In the next section, we turn to the hypotheses on the importance of accessing foreign markets through firm acquisitions.

\subsection{Entering markets through firm acquisition}

Under the increasing pressure of globalization the access to foreign markets is an important factor of today's management strategy. Besides foreign direct investment, firm acquisitions across borders are an important means to access foreign markets 
(Görg, 2000; Kleinert and Klodt, 2000), to acquire an existing distribution network and to benefit from the knowledge of local partners about different cultures and national market conditions. Furthermore, technology sourcing can play an important role for acquisitions across borders as the best possible match is not necessarily located in the same country (Frey and Hussinger, 2006; Sofka, 2007). The potential to transfer valuable intangible assets such as technological know-how between the merged firms is an important reasoning for cross-merger activities from a transaction point of perspective (Seth et al., 2002).

M\&As across borders are however associated with higher information asymmetries than domestic M\&As (Gioia and Thomsen, 2004) and hence with a higher risk of failure (Harris and Ravenscraft, 1991; Swenson, 1993). Transaction cost theory further suggests that transacting across country borders entails additional costs due to a different corporate culture, language barrier, and different national rules in labor and financial markets (Di Giovanni, 2005). To compensate for this additional risk crossborder mergers should generate higher expected benefits than a comparable domestic acquisition (Bertrand and Zungia, 2006). For this reason we argue that expected gains from a cross-border merger are higher than from a comparable domestic M\&A. This should be reflected in the deal value. Hence our fourth hypothesis reads:

Hypothesis 4a: The price paid for a cross-border acquisition target is higher than the price for a domestic target.

Information asymmetries are supposed to be smaller for large established firms as financial and commercial data will be more readily available. Furthermore, the expected gains from M\&As with large players are much higher. Hence we hypothesize:

Hypothesis 4b: The price paid for a cross-border acquisition target is relatively higher for M\&As with a higher deal value than for those with a lower deal value.

The next section explains the empirical model we use to test our hypothesis and introduces our data set. 


\section{Methods}

\subsection{Empirical Model}

The empirical model explains the deal value of the acquisition by the target firm's assets and characteristics. As outlined above, our main focus is on the contribution of different merger motives found in the previous literature as access to technological assets and to foreign markets. In order to get insights into the effects of those different factors on the entire deal value distribution, we have to go beyond standard regression methods, which can only provide information on the average firm, and employ quantile regression (QR) (Koenker and Bassett, 1978; Koenker and Hallock, 2000). In general, quantile regression has several advantages. It accounts for the skewness of the deal value distribution, does not rely on a normality assumption of the error term of the regression model, and is robust to outliers. In contrast, ordinary least squares (OLS) regression is based on the mean of the conditional distribution of the deal value, which implicitly assumes that possible differences in terms of the impact of the exogenous variables along the conditional distribution are not existing or are unimportant. Focusing on the average firm only could hence hold back interesting information, especially in case of a skewed left-hand side variable as is the deal value. Acquisition targets with an extremely low or extremely high takeover price can deliver interesting information on different motivations underlying those M\&As as opposed to the average transaction. In contrast to OLS, QR hence provides snapshots of different points of the deal value distribution. QR has the further advantage over OLS regression to be robust to outliers and heavy-tailed distributions (Buchinsky, 1994).

In our setting targeting at a decomposition of the deal value, we define the acquired company in a hedonic way as a bundle of its characteristics and assets $X$ (Hall, 1988; Gompers and Lerner, 2000). The deal value of the target $V$ is a function of those characteristics $X$. In the presence of efficient markets and full information $V(X)$ would equal the price at which the target firm's assets are traded. Our empirical model then shows how the deal value is decomposed with respect to the target firm's characteristics and assets:

$V_{i}\left(X_{i}\right)=X_{i} \beta_{\theta}+u_{\theta} \quad$ with Quantile $_{\theta}\left(V_{i} \mid X_{i}\right)=X_{i} \beta_{\theta}$, 
where $u$ is the error term of the empirical model, $X$ is the vector of exogenous variables and $\beta_{\theta}$ is the vector of coefficients. Quantile $\theta(V \mid X)$ denotes the $\theta$ th conditional quantile of $V$ given $X$.

The $\theta$ th regression quantile, $0<\theta<1$, is defined as a solution to the problem:

$$
\min _{\beta \in \Re^{k}}\left\{\sum_{i: V_{i} \geq X_{i} \beta} \theta\left|V_{i}-X_{i} \beta\right|+\sum_{i: V_{i}<X_{i} \beta}(1-\theta)\left|V_{i}-X_{i} \beta\right|\right\},
$$

which can be written as:

$$
\min _{\beta \in \mathfrak{R}^{k}} \sum_{i} \rho_{\theta}\left(V_{i}-X_{i} \beta_{\theta}\right)
$$

$\rho_{\theta}(\varepsilon)$ is the so-called absolute value function defined as $\rho_{\theta}(\varepsilon)=\theta \varepsilon$ if $\varepsilon \geq 0$ and $\rho_{\theta}(\varepsilon)=(\theta-1) \varepsilon$ if $\varepsilon<0$. Compared to ordinary least squares, which minimizes the squared sum of residuals, the sum of the absolute residuals is minimized by QR.

\subsection{Data sources and measures}

Our main source of data is the merger and acquisition database ZEPHYR from Bureau van Dijk Electronic Publishing. We identified firms located in Europe that were subject to a horizontal acquisition in the seven-year period from 1997 to 2003. Only targets from the manufacturing sector were included. Our sample consists of 652 target firms with known deal values. Financial information on the firms is taken from Bureau van Dijk Electronic Publishing's Amadeus database. We further linked the acquisition targets to their patent history as patent applicants at the European Patent Office (EPO) in order to get information on their innovation performance. ${ }^{2}$ Based on a computer supported text based search algorithm, target firms and patent applications were linked to each other using firm names and addresses in both databases. Each potential match proposed by the search engine was checked manually.

The main determinant of the takeover price is presumably its total assets. In addition, the expected future benefits should have an impact on the acquisition price. In order to control for that we include returns on assets of the acquisition target, its leverage and its age as additional control variables. The return on assets is defined as the sum

\footnotetext{
${ }^{2}$ Dating patents according to their application date as opposed to the granting date conforms with common practice (e.g., Griliches, 1981). The application date has the advantage of being closer to the actual completion of the invention.
} 
of profits earned by the firm plus the capital gains of assets over the market value of assets in the year prior to the acquisition. The leverage is defined as the total liabilities of the target over total assets in the year prior to the acquisition. Firm age is defined as the number of years since firm foundation. For cross-border acquisitions we use a dummy variable that equals one if the M\&A partners are from different countries.

Focusing on the target's technological assets, we use three variables to capture different aspects of the target companies' innovative activities. All measures are based on the EPO patent information. First, we use a dummy variable that indicates whether the target and acquiring firm are active in the same 2-digit technology field according to the International Patent Classification (IPC). This variable is used to test the importance of being active in the same technology fields as the acquired firm (Hypothesis 1a,b). Second, we use the patent stock $(P S)$ to proxy the number of technologies the firm owns, which is calculated as follows:

$$
P S_{t}=P S_{t-1}(1-\delta)+\text { patent_applications } t_{t}
$$

where $\delta$ represents the constant knowledge depreciation rate, which is set to 15 percent as is standard in the literature (e.g., Hall, 1990). This variable is used to test the importance of the quantity of patents held by the target company for the acquirer (Hypothesis 2a,b). The third variable is the citation rate, which describes the average patent value proxied by the sum of citations the patents received in a five-year window after the patent publication date (Hypothesis 3a,b). Patent citations have frequently been shown to be a reliable measure of patent quality and hence value (Trajtenberg, 1990; Harhoff et al., 2003; Harhoff et al., 2005). Patents receive citations when subsequent patents make reference to relevant prior art during the patent application process. The more frequently a patent is cited by other patents, the higher is its presumable importance in a particular technology field. As the citations a firm receives are highly correlated with its patent stock, we divide the number of citations by the number of patents for our empirical specification. The estimated coefficient can be interpreted as the premium an acquiring firm pays for the value of the target's patents on top of the price paid for the patented technologies themselves. 


\section{Results}

\subsection{Descriptive statistics}

Table 1 presents the descriptive statistics for the sample of target firms. All continuous variables except for the deal value refer to the year prior to completion of the acquisition. The descriptive statistics show a large standard deviation for the deal value in absolute terms and also in logarithm. This underlines the choice of our estimation approach. The high standard deviation is also reflected in the totals assets, which has the highest correlation with the deal value as bivariate correlations show (see Table 3 in the Appendix), and the return on assets. Also, the patent stock and the citation rate show a considerable skewness as has been documented in previous studies (Harhoff et al., 1999; Harhoff et al., 2003). Table 1 further shows that almost 8 percent of the acquisitions occur between firms that are active in the same technology sector. The average firm was founded about 21 years ago. Lastly, almost 44 percent are cross-border deals.

\section{Table 1: Descriptive statistics}

\begin{tabular}{lrrrr}
\hline & Mean & Std. dev. & Min. & Max. \\
\hline Deal value & 103.073 & 317.770 & 1.012 & 3120.000 \\
Log(deal value) & 9.752 & 1.756 & 6.920 & 1.495 \\
Total assets & 160.488 & 309.888 & 0.018 & 2556.000 \\
Log(total assets) & 1.051 & 2.032 & 2.890 & 1.475 \\
Patent stock per total assets & 0.033 & 0.144 & 0.000 & 1.681 \\
Citations per patent & 0.481 & 1.370 & 0.000 & 17.000 \\
Technological relatedness (dummy) & 0.076 & 0.265 & 0.000 & 1.000 \\
Return on assets (percent) & -0.291 & 18.268 & -94.570 & 64.942 \\
Leverage & 0.579 & 0.225 & 0.000 & 1.000 \\
Firm age (years) & 21.399 & 23.865 & 1.000 & 162.000 \\
Cross-border deal (dummy) & 0.437 & 0.496 & 0.000 & 1.000 \\
\hline
\end{tabular}

To further explore the relationships between the variables, Table 3 in the appendix reports the bivariate correlations for all variables. Besides the total assets technological assets and cross-border deals are positively and significantly correlated with the deal value. Based on these findings our hypotheses receive support. The relationships will be further explored in the following section.

\subsection{Multivariate analysis}

Table 2 shows the results from the quantile regression at five different quantiles. The results have to be interpreted as follows. The estimated coefficient for the intercept 
equals the respective quantile of the deal value distribution. For example, the intercept estimate at the 50 percent quantile equals the median of the deal value. The estimated coefficients for binary variables show the deviation from the intercept if the dummy takes a value of one. For continuous variables, the interpretation is analogously to OLS. The difference is just that QR is flexible enough to allow for different slopes at different points of the deal value distribution. The standard errors are bootstrapped using 20 replications. Results do not change if more replications are used. To further illustrate the estimation results of Table 2, Figure 2 shows the results graphically at all 10 percent quantiles. The graphs depict the estimated coefficients of QR and the $95 \%$ confidence intervals and provide a comparison with the OLS estimate for each regressor.

Focusing on the importance of technological assets, the results show that technological relatedness is an important predictor of the deal value. Hypothesis 1a hence receives support. The estimated QR coefficients oscillate closely around the OLS estimate (see Figure 2) indicating that there is no variation along the deal value distribution. There is no difference for acquisition targets associated with a low deal value. Hypothesis $1 \mathrm{~b}$ hence receives no support.

Further, the patent stock as a proxy for the amount of technologies owned by a target firm is an important driver of the deal value at all quantiles of the distribution (hypothesis 2a). The importance of patents decreases however at the higher quantiles. Figure 2 shows that the QR coefficient lies below the OLS estimate at the higher quantiles. The standard errors are smaller at the higher quantiles, which indicates that the estimates are even more precise here than at the lower quantiles. Hence, the size of the patent portfolio tends to loose in importance at the higher quantiles and OLS overestimates the importance of the patent stock for acquisitions associated with a high deal value. ${ }^{3}$ Hence, we find some support for hypothesis $2 b$.

A similar result is obtained for the value of patents as measured by the citation rate. The value of patents is especially important at the lower quantiles. ${ }^{4}$ It is not statistically significant from zero at the higher quantiles as the standard errors increase at this part of the distribution. This shows that the estimated coefficients are less

\footnotetext{
${ }^{3}$ The QR results are significantly different from the OLS estimates at the $90 \%$-quantile.

${ }^{4}$ The QR results are significantly different from the OLS estimates at the $20 \%$-quantile.
} 
precise here indicating that there is a great heterogeneity of acquisition objectives at the upper end of the deal value distribution with respect to the importance of patent value. The results support hypotheses $3 \mathrm{a}$ and $3 \mathrm{~b}$.

To summarize the findings with respect to technology, being active in the same technology field is of high value to the acquiring firm in any acquisition. Acquirers are hence willing to pay for technological assets that provide opportunities for crossfertilization. Also, information asymmetries between M\&A partners in the same technology fields are supposed to be smaller than for others. Further, patents are in terms of quantity and quality more important for firms with a lower deal value than for mega-mergers. This can be the case as takeovers might be more attractive than technology contracts at arm's-length with small acquisition targets. Moreover, patents work as a signal for the technological fitness of a potential target company, which is supposed to be of higher importance for firms at the lower end of the deal value distribution, where the small and private firms are located.

With respect to the access to foreign markets as a merger objective, the estimated effect increases along the deal value distribution. Figure 2 shows that OLS would tend to overestimate the impact of cross-border acquisitions at the lower end of the distribution and underestimate the effect at the higher quantiles. ${ }^{5}$ Acquisitions across borders are hence rather associated with a high deal value than with a low deal value. For large acquisition targets, information asymmetries are likely to be smaller. Further, they are presumably associated with a larger market share and a better customer and distribution network in their domestic market than smaller firms.

Apart from the variables of main interest, the results show that total assets are a major determinant of the deal value and also most closely related to the deal value distribution. The largest deviation of the QR estimates from the OLS estimates can be found here as Figure 2 shows. ${ }^{6}$ Referring to the return on assets, there is a positive but small effect on the deal value. Apparently, the higher the profitability of the target the higher the deal value will be which makes intuitively sense as those targets provide more opportunities to recover the acquisition price. This effect decreases drastically

\footnotetext{
${ }^{5}$ It cannot be found that OLS and QR results are significantly different from each other, which is most likely explained by the small size of our sample.

${ }^{6}$ OLS significantly overestimates the effect of total assets at the $10 \%$-30\%-quantiles and significantly overestimates the effect at the $60 \%-90 \%$-quantiles.
} 
along the conditional deal value distribution. ${ }^{7}$ Apparently, the refinancing issue is most important for medium-sized acquisitions. With respect to firm age, the OLS estimate seem to overestimates the effect on deal value at almost all quantiles. ${ }^{8}$ In fact, firm age, which is supposed to correlate with firm reputation and the development of internal structures within the firm, increases in importance along the conditional deal value distribution. Finally, there is no effect of the leverage of the target firm on the deal value.

It is also worthwhile to notice that it is most difficult to predict the determinants of the highest value acquisitions. For many variables (e.g. patent value, cross-border acquisitions and leverage), the $95 \%$ confidence interval becomes relatively large at the end of the deal value distribution indicating that there is more heterogeneity of the targets with a high deal value. In a similar vein, many of the influencing factors (e.g. patent stock and return on assets) show a stronger or less strong effect at the highest quantiles if compared to the average effect.

\footnotetext{
${ }^{7}$ The QR results are significantly different from the OLS estimates at the $90 \%$-quantile.

${ }^{8}$ The estimated QR coefficients are however not statistically significant from the OLS estimates at any convenient level of statistical significance.
} 
Table 2: Quantile regression for the deal value

\begin{tabular}{|c|c|c|c|c|c|}
\hline $\begin{array}{l}\text { Quantile } \\
\text { Variables } \\
\end{array}$ & $\begin{array}{c}\text { Q10 } \\
\text { Coef. } \\
\text { (std.err.) }\end{array}$ & $\begin{array}{c}\text { Q25 } \\
\text { Coef. } \\
\text { (std. err.) } \\
\end{array}$ & $\begin{array}{c}\text { Q50 } \\
\text { Coef. } \\
\text { (std. err.) } \\
\end{array}$ & $\begin{array}{c}\text { Q75 } \\
\text { Coef. } \\
\text { (std. err.) } \\
\end{array}$ & $\begin{array}{c}\text { Q90 } \\
\text { Coef. } \\
\text { (std. err.) }\end{array}$ \\
\hline Log(total assets) & $\begin{array}{c}0.18 * * * \\
(0.03)\end{array}$ & $\begin{array}{c}0.29 * * * \\
(0.05)\end{array}$ & $\begin{array}{c}0.39 * * * \\
(0.04)\end{array}$ & $\begin{array}{c}0.48 * * * \\
(0.05)\end{array}$ & $\begin{array}{c}0.45 * * * \\
(0.08)\end{array}$ \\
\hline Patent stock per total assets & $\begin{array}{c}2.25 * * * \\
(0.66)\end{array}$ & $\begin{array}{c}2.33 * * * \\
(0.86)\end{array}$ & $\begin{array}{c}2.24 * * * \\
(0.55)\end{array}$ & $\begin{array}{c}1.76^{* * *} \\
(0.48)\end{array}$ & $\begin{array}{l}1.03 * * \\
(0.50)\end{array}$ \\
\hline Citations per patent & $\begin{array}{c}0.08 \\
(0.05)\end{array}$ & $\begin{array}{c}0.17 * * * \\
(0.05)\end{array}$ & $\begin{array}{c}0.12 \\
(0.07)\end{array}$ & $\begin{array}{c}0.04 \\
(0.07)\end{array}$ & $\begin{array}{c}0.06 \\
(0.11)\end{array}$ \\
\hline Technological relatedness & $\begin{array}{c}0.78 * * * \\
(0.26)\end{array}$ & $\begin{array}{c}0.60 * * \\
(0.27)\end{array}$ & $\begin{array}{l}0.56^{* *} \\
(0.28)\end{array}$ & $\begin{array}{l}0.74 * * \\
(0.31)\end{array}$ & $\begin{array}{c}0.73 * * \\
(0.30)\end{array}$ \\
\hline Return on assets & $\begin{array}{c}0.01 * * * \\
(0.00)\end{array}$ & $\begin{array}{c}0.02 * * * \\
(0.00)\end{array}$ & $\begin{array}{c}0.02 * * * \\
(0.00)\end{array}$ & $\begin{array}{l}0.01 * * \\
(0.00)\end{array}$ & $\begin{array}{c}0.00 \\
(0.00)\end{array}$ \\
\hline Leverage & $\begin{array}{c}-0.73^{* *} \\
(0.36)\end{array}$ & $\begin{array}{l}-0.40 \\
(0.32)\end{array}$ & $\begin{array}{l}-0.57 \\
(0.39)\end{array}$ & $\begin{array}{l}-0.31 \\
(0.43)\end{array}$ & $\begin{array}{l}-0.35 \\
(0.55)\end{array}$ \\
\hline Firm age & $\begin{array}{c}0.00 \\
(0.00)\end{array}$ & $\begin{array}{l}0.01 * \\
(0.00)\end{array}$ & $\begin{array}{c}0.01 \\
(0.00)\end{array}$ & $\begin{array}{c}0.01 * * * \\
(0.00)\end{array}$ & $\begin{array}{l}0.01 * \\
(0.00)\end{array}$ \\
\hline Cross-border deal & $\begin{array}{c}0.22 \\
(0.15)\end{array}$ & $\begin{array}{c}0.39 * * * \\
(0.16)\end{array}$ & $\begin{array}{l}0.39 * \\
(0.21)\end{array}$ & $\begin{array}{c}0.57 * * * \\
(0.17)\end{array}$ & $\begin{array}{l}0.54 * * \\
(0.17)\end{array}$ \\
\hline Constant & $\begin{array}{c}5.72 * * * \\
(0.53)\end{array}$ & $\begin{array}{c}5.13 * * * \\
(0.35)\end{array}$ & $\begin{array}{c}5.17 * * * \\
(0.69)\end{array}$ & $\begin{array}{c}5.19 * * * \\
(0.74)\end{array}$ & $\begin{array}{c}6.78 * * * \\
(1.20)\end{array}$ \\
\hline $\begin{array}{l}\text { Industry dummies } \\
\text { Year dummies }\end{array}$ & & & $\begin{array}{l}\text { Yes } \\
\text { Yes }\end{array}$ & & \\
\hline \# obs. & & & 652 & & \\
\hline Pseudo-R $^{2}$ & 0.12 & 0.15 & 0.20 & 0.25 & 0.28 \\
\hline
\end{tabular}

Standard errors are bootstrapped using 20 replications.

Figure 2: Graphical presentation of the regression results
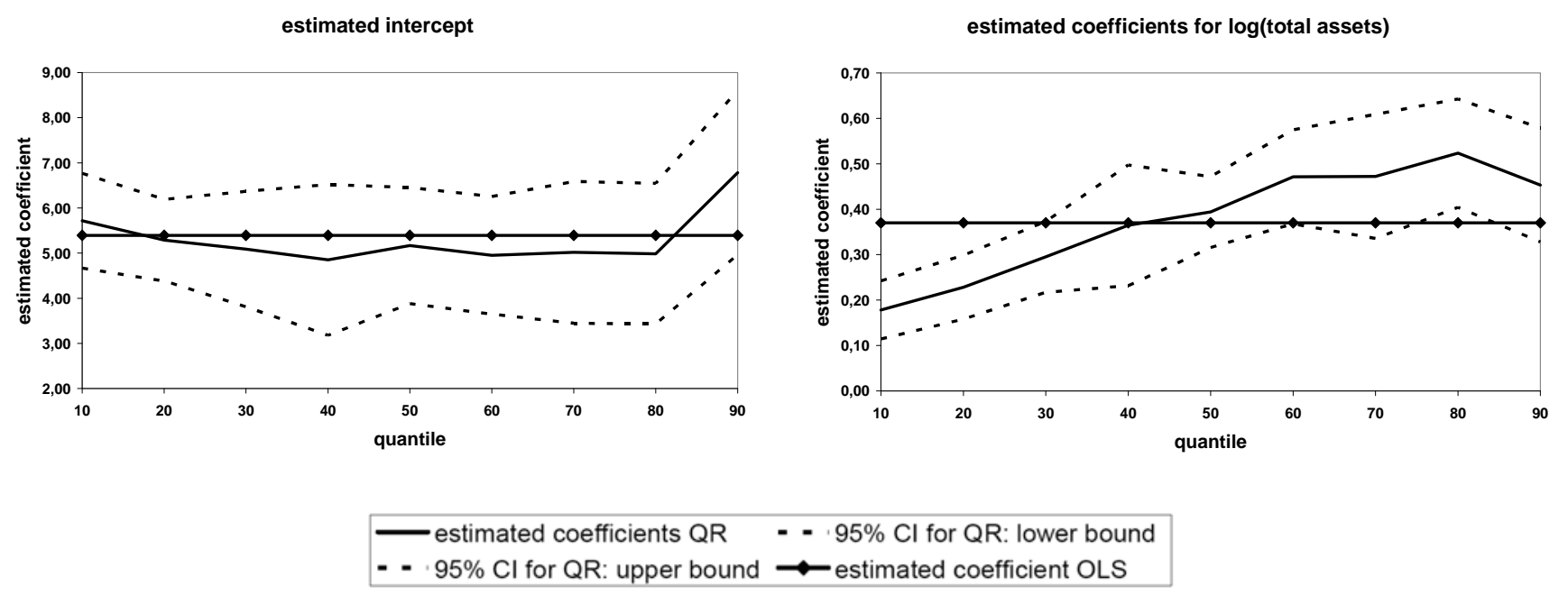

... to be continued 
Figure 2 continued

estimated coefficients for patent stock per total assets

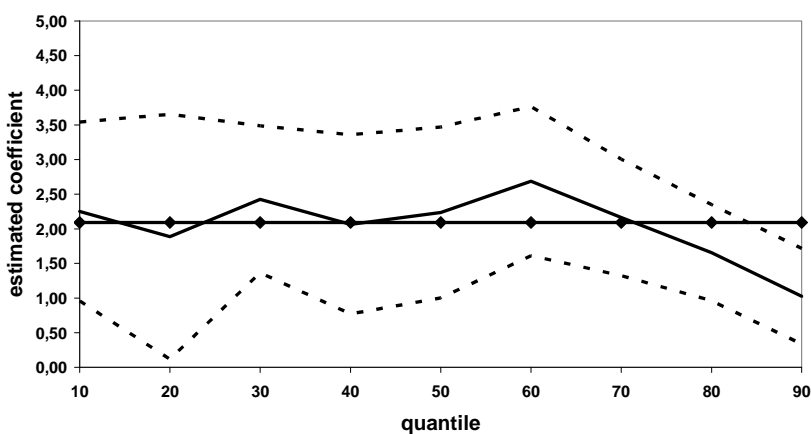

estimated coefficients for being active in the same technology field

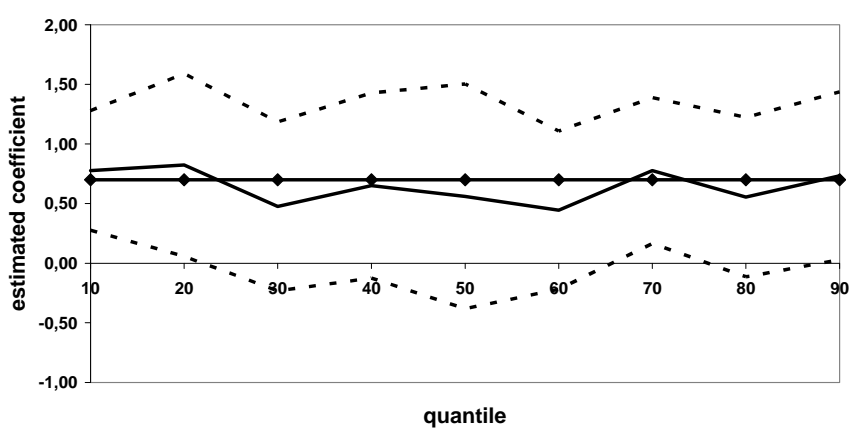

estimated coefficients for return on assets

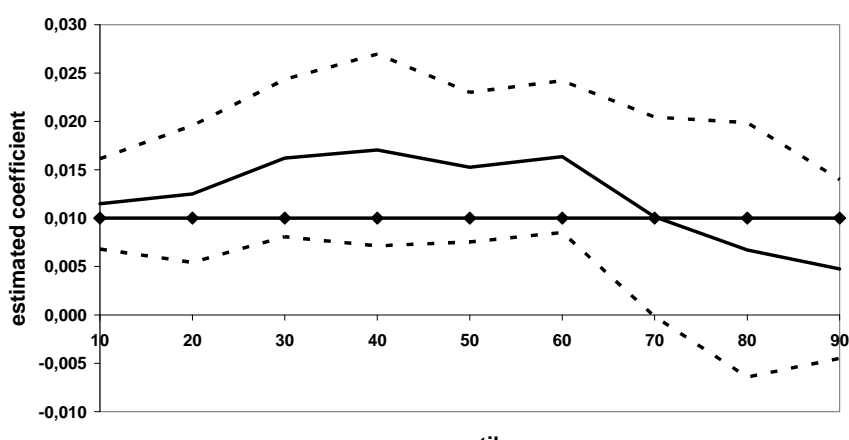

estimated coefficients for citations per patent

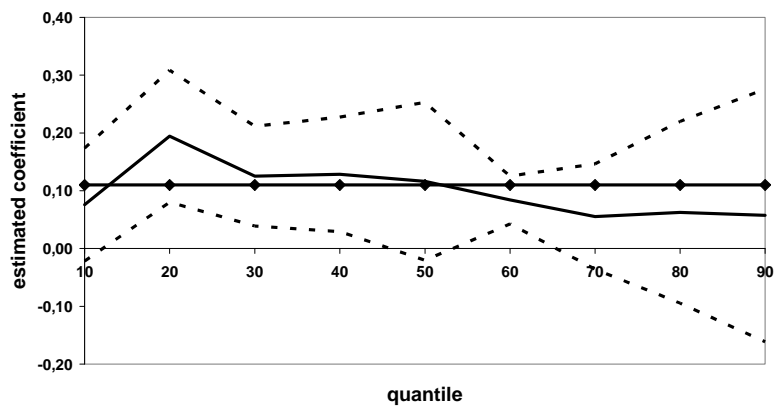

estimated coefficients for cross-border M\&As

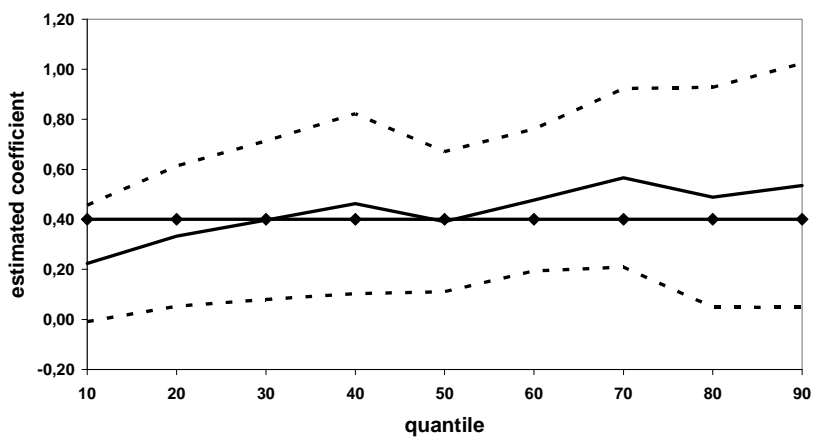

estimated coefficients for liabilities over total assets

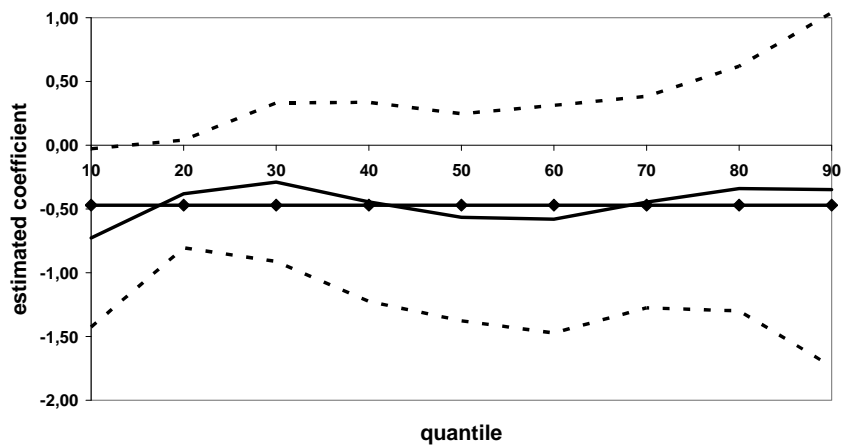

... to be continued 
Figure 2 continued

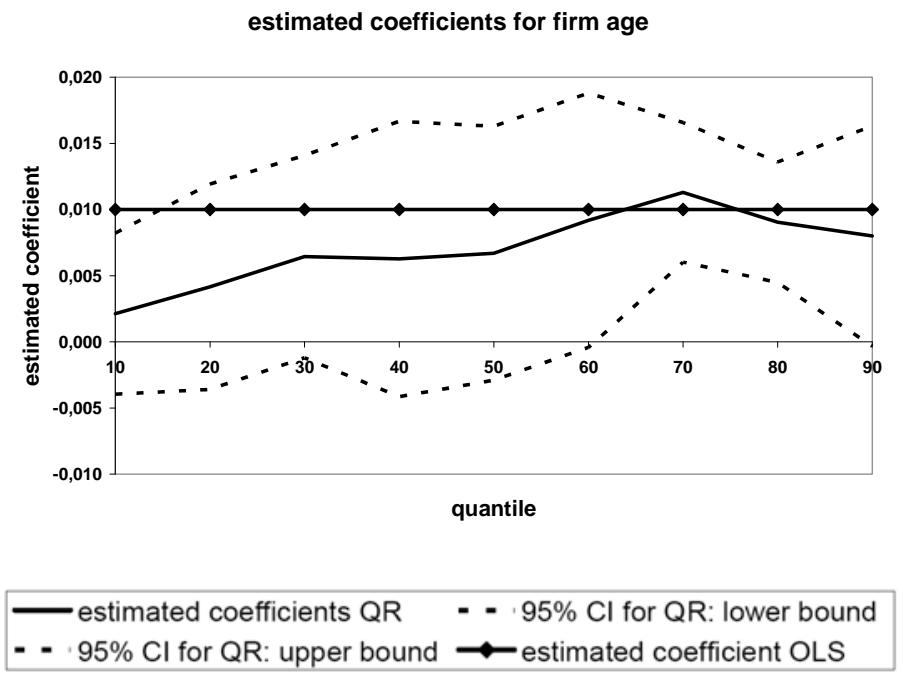

\section{Discussion}

Our results have shown that the importance of takeover motivations varies along the deal value distribution. Whereas the acquisition of technologies in the fields of own expertise is important for all M\&As, the volume and value of the acquired technologies is relatively more important for firms associated with a lower deal value. The first result suggests that valuable technology that can be used in combination with existing technology to appropriate the returns from innovation activities is highly important in all acquisitions. Those acquisitions can be driven by the information advance over competitors unskilled in the field of technical expertise, which can be grounded in the absorptive capacity of an acquiring firm (Cohen and Levinthal, 1989, 1990). Moreover, such acquisitions may be directly targeted at improving the position of the acquiring firm in technology markets through accumulating technologies and combining them with existing know-how in order to achieve a competitive advantage over competitors. Furthermore, such takeovers have the potential to block competitor technologies or to "unlock" existing technology fences (Grimpe and Hussinger, 2008). Our results have demonstrated that the technological content and the opportunity to exploit protected knowledge in combination with one's own knowledge stocks are of great importance. Acquirers deliberately strive to 
complement their own technology portfolio by redeploying technological resources in order to increase their own innovative capabilities (Cassiman et al., 2005; Hussinger, 2005; Sorescu et al., 2007).

A on the one hand large and on the other hand highly valuable patent portfolio is, in contrast, relatively more important for acquisitions associated with a relatively low deal value. Acquiring firms obviously succeed in identifying valuable technology employed by small target companies. They are found to pay relatively higher prices for small acquisition targets with large but also with valuable technological assets. From a transaction cost perspective, this result makes sense as the costs of the acquisition of a small firm with important technological assets might outweigh the costs of technology contracts at arm's-length. The internal exploitation of those resources has the advantage of avoiding monitoring problems and the emergence of strong future competitors.

Focusing on non-technological assets, our results show that the objective to acquire another firm to access a foreign market is more pronounced for large firms. Those firms typically have a significant market share in their domestic market as well as a well-developed customer and distribution network. On top, foreign firms can also be attractive because of their intangible assets like technological know-how (Seth et al., 2002). Being located in different countries however increases information asymmetries. Information on large firms is supposed to be more easily available and more reliable. Hence, gaining access to international markets is associated with a larger deal value.

In this respect, our results extend existing knowledge on the motivation for firm acquisitions. For the first time, the two major objectives of takeovers - technology and access to foreign markets - are shown to be of different importance in the market for corporate control depending on the deal value. In particular, the technology objective behind mergers and acquisitions is more important for smaller deals, whereas the access of foreign markets is a major driver behind larger M\&As.

Although the bulk of attention in the public press is devoted to mega-mergers, the tendency to acquire small innovative companies can drastically increase concentration in technology markets. This links our results to an important implication for competition policy. M\&A transactions of small firms are also likely to create barriers 
to entry in specific technology markets and, hence, decrease competition (Aydemir and Schmutzler, 2008). Merger control authorities should therefore generally have an eye on the concentration of key technologies in the market as there is currently no systematic evaluation procedure of the technology dimension laid down in merger regulation. In particular, it might be misleading to focus on large mergers only when it comes to technology markets. Technology seems to be relatively more important for acquisitions of smaller firms that own important technologies. Given the large share of relatively small acquisitions in the total number of acquisitions, however, makes clear that this will pose a major challenge to merger control authorities.

Further, a tendency towards concentration in technology markets also needs to be reflected in the technology strategy of firms that do not merge. Firms need to keep a careful eye on the key technologies in their industry and identify the underlying intellectual property. They need to understand that reorganization in the industry through M\&A transactions could be directed at a concentration of key technologies.

Coming back to mega-mergers, there is a tendency that those are predominantly international transactions. This shows that concentration does not stop at national borders. In contrast to small M\&As, international mergers are however carefully scrutinized by competition authorities.

\section{Conclusion and future research}

This paper has examined a sample of European firm acquisitions and shown that technology as well as the access to foreign markets matters considerably in firm acquisitions in that both merger objectives prove to be major drivers for the deal value. The results further show that technologies are more important for acquisitions associated with a low deal value whereas internationalization is rather important for large acquisitions. This shows two different trends for market consolidation targeting at different potential acquisition targets. Our results, however, provide no indication on the implications of both types of concentration on competitors in the industry. Future research should therefore try to compare the effects of concentration in technology markets, which involves rather small firms, with international concentration among the big players in the market. Moreover, it would be interesting to see whether the relationship between takeover motivation and deal value changes over time. It could be argued that with international trade and foreign direct 
investment barriers being brought down in the last decade there is a trend towards larger international acquisitions. Such an investigation would, however, require detailed deal information in a longitudinal framework which will not be readily available. 


\section{References}

Aboody, D. and B. Lev (2000), Information Asymmetry, R\&D, and Insider Gains, Journal of Finance 55, 2747-2766.

Ahuja, G. and R. Katila (2001), Technological Acquisitions and the Innovation Performance of Acquiring Firms: A Longitudinal Study, Strategic Management Journal 22 (3), 197-220.

Aydemir, Z. and A. Schmutzler (2008), Small Scale Entry Versus Acquisitions of Small Firms: Is Concentration Self-Reinforcing?, Journal of Economic Behavior \& Organization 65, 133-146.

Barney, J.B. (1991), Firm Resources and Sustained Competitive Advantage, Journal of Management 17 (1), 99-120.

Bertrand, O. and P. Zungia (2006), R\&D and M\&A: Are Cross-Border M\&a Different? An Investigation on Oecd Countries, International Journal of Industrial Organization 24, 401-423.

Black, B.S. (2000), The First International Merger Wave (and the Fifth and Last U.S. Wave), University of Miami Law Review 54, 799-818.

Bowman, E.H. and D. Hurry (1993), Strategy through the Option Lens: An Integrated View of Resource Investments and the Incremental-Choice Process, Academy of Management Review 18 (4), 760-782.

Bowman, E.H. and H. Singh (1993), Corporate Restructuring: Reconfiguring the Firm, Strategic Management Journal 14, 5-14.

Buchinsky, M. (1994), Changes in U.S. Wage Structure 1963-1987: An Application of Quantile Regression, Econometrica 62 (2), 405-458.

Capron, L., P. Dussauge and W. Mitchell (1998), Resource Redeployment Following Horizontal Acquisitions in Europe and North America, Strategic Management Journal 19, 631-661.

Capron, L. and J. Hulland (1999), Redeployment of Brands, Sales Forces, and General Marketing Management Expertise Following Horizontal Acquisitions: A Resource-Based View, Journal of Marketing 63 (2), 41-54. 
Capron, L. and J.-C. Shen (2007), Acquisitions of Private Vs. Public Firms: Private Information, Target Selection, and Acquirer Returns, Strategic Management Journal 28/, 891-911.

Cassiman, B., M.G. Colombo, P. Garrone and R. Veugelers (2005), The Impact of M\&a on the R\&D Process. An Empirical Analysis of the Role of Technological- and Market-Relatedness, Research Policy 34, 195-220.

Cassiman, B. and R. Veugelers (2005), In Search of Complementarity in the Innovation Strategy: Internal R\&D and External Knowledge Acquisition, No.

Caves, R.E. (1989), Exchange-Rate Movements and Foreign Direct Investment in the United States, in: Audretsch, D. B. and M. P. Claudon (eds.), The Internationalization of U.S. Markets, New York, 199-228.

Chakrabarti, A.K., J. Hauschildt and C. Süverkrüp (1994), Does It Pay to Acquire Technological Firms?, R\&D Management 24 (1), 47-56.

Cohen, B.D. and T.J. Dean (2005), Information Asymmetry and Investor Valuation of Ipos: Top Management Team Legitimacy as a Capital Market Signal, Strategic Management Journal 26, 683-690.

Cohen, W.M. and D.A. Levinthal (1989), Innovation and Learning: The Two Faces of R\&D, The Economic Journal 99 (397), 569-596.

Cohen, W.M. and D.A. Levinthal (1990), Absorptive Capacity: A New Perspective on Learning and Innovation, Administrative Science Quarterly 35 (1), 128-152.

Cohen, W.M. and D.A. Levinthal (1994), Fortune Favors the Prepared Firm, Management Science 40 (2), 227-251.

Colombo, M.G., L. Grilli and E. Piva (2006), In Search of Complementary Assets: The Determinants of Alliance Formation of High-Tech Start-Ups, Research Policy 35, 1166-1199.

Conner, K.R. (1991), A Historical Comparison of Resource-Based Theory and Five Schools of Thought within Industrial Organization Economics. Do We Have a New Theory of the Firm?, Journal of Management 17 (1), 121-154. 
Di Giovanni, J. (2005), What Drives Capital Flows? The Case of Cross-Border M\&a Acitivity and Financial Deepening, Journal of Industrial Economics 65 (1), 127-149.

Dunning, J.H. (1988), The Eclectic Paradigm of International Production: A Restatement and Some Possible Extensions, Journal of International Business Studies 19 (1), 1-31.

Eisenhardt, K.M. and J.A. Martin (2000), Dynamic Capabilities: What Are They?, Strategic Management Journal 21 (10/11), 1105-1121.

Fama, E.F. (1970), Efficient Capital Markets: A Review of Theory and Empirical Work, Journal of Finance 25, 383-417.

Frey, R. and K. Hussinger (2006), The Role of Technologies in M\&As: A Firm-Level Comparison of Cross-Border and Domestic Deals, ZEW Discussion Paper No. 6-69, Mannheim.

Gioia, C. and S. Thomsen (2004), International Acquisitions in the Danish Business: Selection and Performance.

Gompers, P. and J. Lerner (2000), Money Chasing Deals? The Impact of Fund Inflows on Private Equity Valuations, Journal of Financial Economics 55, 281-325.

Görg, H. (2000), Analysing Foreign Market Entry: The Choice between Greenfield Investment and Acquisitions, Journal of Economic Studies 27 (3), 165-181.

Graebner, M. (2004), Momentum and Serendipity: How Acquired Leaders Create Value in the Integration of Technology Firms, Strategic Management Journal $25,751-777$.

Graff, G.D., G.C. Rausser and A.A. Small (2003), Agricultural Biotechnology's Complementary Intellectual Assets, The Review of Economics and Statistics 85 (2), 349-363.

Griliches, Z. (1981), Market Value, R\&D and Patents, Economics Letters 7, 183-187.

Grimpe, C. (2007), Successful Product Development after Firm Acquisitions: The Role of Research and Development, Journal of Product Innovation Management 24, 614-628. 
Grimpe, C. and K. Hussinger (2008), Pre-Empting Technology Competition through Firm Acquisitions, Economics Letters forthcoming.

Hagedoorn, J. and G. Duysters (2002), The Effect of Mergers and Acquisitions on the Technological Performance of Companies in a High-Tech Environment, Technology Analysis \& Strategic Management 14 (1), 67-85.

Hall, B.H. (1988), The Effect of Takeover Activity on Corporate Research and Development, in: Auerbach, A. J. (ed.) From Corporate Takeovers. Causes and Consequences, Chicago et al., 69-100.

Hall, B.H. (1990), The Manufacturing Sector Master File: 1959-1987, NBER Working Paper No. 3366, Cambridge, MA.

Harhoff, D., K. Hoisl and C. Webb (2005), European Patent Citations. How to Count and How to Interpret Them, LMU Discussion Papers No., Munich.

Harhoff, D., F. Narin, F.M. Scherer and K. Vopel (1999), Citation Frequency and the Value of Patented Inventions, The Review of Economics and Statistics 81 (3), 511-515.

Harhoff, D., F.M. Scherer and K. Vopel (2003), Citations, Family Size, Opposition and the Value of Patent Rights, Research Policy 32, 1343-1363.

Harris, R. and D. Ravenscraft (1991), The Role of Acquisitions in Foreign Direct Investment: Evidence from the U.S. Stock Market, Journal of Finance 46, 825-844.

Heeley, M.B., S.F. Matusik and N. Jain (2007), Innovation, Appropriability, and the Underpricing of Initial Public Offerings, Academy of Management Journal 50 (1), 209-225.

Heller, M.A. and R.S. Eisenberg (1998), Can Patents Deter Innovation? The Anticommons in Biomedical Research Science 280 (5364), 698-701.

Hussinger, K. (2005), Did Concentration on Core Competencies Drive Merger and Acquisition Activities in the 1990s?, ZEW Discussion Paper No. 5-41, Mannheim. 
Jensen, M.C. and R.S. Ruback (1983), The Market for Corporate Control, Journal of Financial Economics 11, 5-50.

Kleinert, J. and H. Klodt (2000), Megafusionen.

Koenker, R. and G. Bassett (1978), Regression Quantiles, Econometrica 46 (1), 33 50 .

Koenker, R. and K. Hallock (2000), Quantile Regression: An Introduction, http://www.econ.uiuc.edu/ roger/research/intro/rq.pdf.

Lerner, J., J. Tirole and M. Strojwas (2003), Cooperative Marketing Agreements between Competitors: Evidence from Patent Pools, NBER Working Paper No. 9680, Cambridge, MA.

Levitas, E. and M.A. McFadyen (2006), Managing Liquidity in Research-Intensive Firms: Signaling Effects of Patents \& Managerial Ownership, Academy of Management Proceedings, G1-G6.

Mukherjee, T.K., H. Kiymaz and H.K. Baker (2004), Merger Motives and Target Valuation. A Survey of Evidence from Ceos, Journal of Applied Finance 14 (2), 7-24.

Ndofor, H.A. and E. Levitas (2004), Signaling the Strategic Value of Knowledge, Journal of Management 30 (5), 685-702.

O'Donoghue, T., S. Scotchmer and J.-F. Thisse (1998), Patent Breadth, Patent Life and the Pace of Technological Progress, Journal of Economics and Management Strategy 7, 1-32.

Pakes, A. (1985), On Patents, R\&D, and the Stock Market Rate of Return, Journal of Political Economy 93, 390-409.

Penrose, E.T. (1959), The Theory of the Growth of the Firm, Oxford.

Peteraf, M.A. (1993), The Cornerstones of Competitive Advantage: A ResourceBased View, Strategic Management Journal 14 (3), 179-191. 
Priem, R.L. and J.E. Butler (2001), Is the Resource-Based "View" A Useful Perspective for Strategic Management Research?, Academy of Management Review 26 (1), 22-40.

Qiu, L.D. and W. Zhou (2006), International Mergers: Incentives and Welfare, Journal of International Economics 68, 38-58.

Röller, L.-H., J. Stenneck and F. Verboven (2001), Efficiency Gains from Mergers.

Scherer, F.M. and D. Ross (1990), Industrial Market Structure and Economic Performance, Boston, MA.

Seth, A., K.P. Song and R.R. Pettit (2002), Value Creation and Destruction in CrossBorder Acquisitions: An Empirical Analysis of Foreign Acquisitions of U.S. Firms, Strategic Management Journal 23, 921-940.

Shapiro, C. (2001), Navigating the Patent Thicket: Cross Licenses, Patent Pools, and Standard Setting, in: Jaffe, A., J. Lerner and S. Stern (eds.), Innovation Policy and the Economy, Cambridge, MA, 119-150.

Shen, J.-C. and J.J. Reuer (2005), Adverse Selection in Acquisitions of Small Manufacturing Firms: A Comparison of Private and Public Targets, Small Business Economics 24, 393-407.

Sofka, W. (2007), What Makes Foreign Knowledge Attractive to Domestic Innovation Managers?, ZEW Discussion Paper No. 07-055, Mannheim.

Sorescu, A.B., R.K. Chandy and J.C. Prahbu (2007), Why Some Acquisitions Do Better Than Others: Product Capital as a Driver of Long-Term Stock Returns, Journal of Marketing Research 44, 57-72.

Sutton, J. (1991), Sunk Costs and the Market Structure, Cambridge, MA.

Swenson, D. (1993), Foreign Mergers and Acquisitions in the United States, in: Froot, K. A. (ed.) Foreign Direct Investment, Chicago, IL.

Teece, D.J. (1988), Technological Change and the Nature of the Firm, in: Dosi, G., C. Freeman, R. R. Nelson, G. Silverberg and L. Soete (eds.), Technical Change and Economic Theory, London, New York, 256-281. 
Trajtenberg, M. (1990), A Penny for Your Quotes: Patent Citations and the Value of Innovation, RAND Journal of Economics 21 (1), 172-187.

Williamson, O.E. (1985), The Economic Institutions of Capitalism: Firms, Markets, Relational Contracting, New York.

Ziedonis, R.H. (2004), Don't Fence Me In: Fragmented Markets for Technology and the Patent Acquisition Strategies of Firms, Management Science 50 (6), 804820. 


\section{Appendix}

Table 3: Bivariate correlations

\begin{tabular}{|c|c|c|c|c|c|c|c|c|c|c|c|c|c|c|c|c|}
\hline Variable & 1. & & 2. & & 3. & & 4. & & 5. & & 6. & & 7. & & 8. & 9. \\
\hline 1. $\log ($ deal value $)$ & 1.00 & & & & & & & & & & & & & & & \\
\hline 2. $\log$ (total assets) & 0.42 & $* * *$ & 1.00 & & & & & & & & & & & & & \\
\hline 3. Patent stock per total assets & 0.25 & $* * *$ & 0.09 & $* *$ & 1.00 & & & & & & & & & & & \\
\hline 4. Citations per patent & 0.16 & $* * *$ & 0.08 & $*$ & 0.10 & $* * *$ & 1.00 & & & & & & & & & \\
\hline 5. Technological relatedness & 0.24 & $* * *$ & 0.13 & $* * *$ & 0.26 & $* * *$ & 0.14 & $* * *$ & 1.00 & & & & & & & \\
\hline 6. Return on assets & 0.05 & & -0.14 & $* * *$ & -0.10 & $* * *$ & 0.00 & & -0.05 & & 1.00 & & & & & \\
\hline 7. Leverage & -0.02 & & 0.17 & $* * *$ & -0.03 & & -0.01 & & -0.07 & $*$ & 0.04 & & 1.00 & & & \\
\hline 8. Firm age & 0.13 & $* * *$ & 0.02 & & 0.04 & & 0.06 & & 0.03 & & 0.09 & $* *$ & -0.08 & $*$ & 1.00 & \\
\hline 9. Cross-border deal & 0.14 & $* * *$ & 0.07 & $*$ & 0.04 & & -0.01 & & 0.11 & $* * *$ & -0.05 & & 0.02 & & -0.04 & 1.00 \\
\hline
\end{tabular}

